\title{
RETREATING RIGHTS: HUMAN RIGHTS, PRE-THEORETICAL PRAXES AND STUDENT ACTIVISM IN SOUTH AFRICAN UNIVERSITIES
}

\author{
A. Keet \\ Chair, Critical Studies in Higher Education Transformation \\ Nelson Mandela University \\ Port Elizabeth, South Africa \\ e-mail: andre.keet@mandela.ac.za
}

\section{W. Nel*}

School of Education Studies

e-mail: nelwn@ufs.ac.za

\section{S.D. Sattarzadeh*}

Institute for Reconciliation and Social Justice

e-mail: sattarzadehsd@ufs.ac.za

*University of the Free State

Bloemfontein, South Africa

\section{ABSTRACT}

This article is a recognition-theoretical reading of a research-study on pre-theoretical understandings of human rights amongst university students as ways to logically anchor agential options for student social activism. The study shows that the expected legal and political constructions of human rights are discursively dominant. However, from the overall results of the study, it appears students have more complex pre-theoretical understandings of human rights from which they derive justice-orientations as sources for activism. We conclude this has deliberative implications for human rights praxes.

Keywords: human rights, pre-theoretical praxis, student activism, recognition theory, higher education, governmentality

\section{INTRODUCTION}

This article is the second article of a series that captures our ongoing research on contemporary expressions of the notion of rights and citizenship in university settings. ${ }^{1}$ The research project is steered by the idea of transformative student citizenship. ${ }^{2}$ In the first paper, 'Rights, regulation and recognition' (Keet and Nel 2016), we report on the first phase of our research 
project that probed the following question: 'Why do successive groups of student leaders feel misrecognised within university arrangements and practices that are meant to broaden democratic spaces as far as their participation is concerned?' The findings put our assumptions relating to recognition as a function of democratic participation and the justice-making potential of rights within formal institutions in doubt. Futhermore, the exercise of rights and democratic participation do not necessarily contribute to recognitive justice within university settings; though we presuppose there is a positive link between the exercise of rights and recognitive justice.

This article reflects on the second phase of the research project and focuses on students' framing of human rights in higher education institutions, building on the first phase of our inquiry by exploring the apparent contradictory idea of human rights as un/freedoms insofar as human rights both facilitate and constrain the agential capacities of students. The mapping of the inconsistencies and contradictions between rights and recognition in the first phase (Keet and Nel 2016) provides the basis for articulating our main research question in the second phase. As the conception of rights in its codified forms expands to 'supposedly' facilitate agency and empowerment, we pose these questions: Why do students feel increasingly trapped by smothered activisms in seemingly rights-friendly policy environments; and secondly, from where, if anywhere, do students mobilise alternative sources for social activism? To respond to these questions, we designed this phase of the study around pre-theoretical understandings of both human rights and citizenship to probe the standpoints that students may hold as they engage with these concepts and its expressions within the university.

\section{BACKGROUND TO THE STUDY}

In an account of the first phase of our study in 'Rights, regulation and recognition' (Keet and Nel 2016), we briefly reflected on the historical racialised arrangements in South African higher education, as imported into the present. We also sketchily engaged with the transformation trajectory of the University of the Free State (UFS), a historically White-Afrikaner university. As we reflect on the first phase of the study it became apparent that human rights are increasingly experienced and viewed as constitutive of over-regulated practices, a point potently made by Honig (2001, 800). However, the value of human rights as a force in service of social justice cannot summarily be discounted. ${ }^{3}$ Rather, we are called upon to explore the social processes by which its activist potential is weakened, so as to retreat it, which will be expanded upon later.

Student participation, a key element of university citizenship, includes transformational 
and activist dimensions. The international and national history of student participation, student governance and student politics within universities have been analysed in various studies (Luescher 2015; Luescher, Klemenčič and Jowi 2016). Against this backdrop we argue that student participation in university life may displace the social justice project for which it was designed. The scholarly puzzle that emerged in phase one of the study relates to how student leaders frame their experiences as 'acting out scripts' in an 'overregulated space'. We thus highlighted the need to rethink student citizenship against the backdrop of the university as an institution embodied in techniques of regulation and governmentality.

In phase two of the study, we raise the stakes for our inquiry. Looking beyond the challenges of 'overregulation' and questioning the shared misplaced truth of the contingent link between human rights and the expansion of democratic practice (ibid.) through the prism of rights critiques, we not only explore how rights-friendly policy environments seemingly smothers social activism, but we also consider the alternative sources for radical action that students mobilise. The findings from this phase of the study show that though legal, political and policy constructions are dominant in students' understandings on human rights, complex pre-theoretical orientations feature strongly in students' responses from which they draw alternative resources for activism. This reliance has daunting yet exciting implications for human rights praxes in university settings.

\section{CONTEXTUAL AND CONCEPTUAL FRAMES}

The policy architecture of student governance in higher education is rooted in the principles of human rights and democracy, pleated into what is generally regarded as South Africa's overarching socio-legal scheme of 'transformative constitutionalism'; though it is probably more accurate to describe it as a bare form of idolatry that results in 'non-thinking in the name of the normative' (Butler 2010, 136). The Constitution sets up 'normative' rights-bearingsubjects that stream our entire political consciousness without questioning what the norm is 'according to which the subject is produced who then becomes the presumptive "ground" of normative debate' (Butler 2010, 139. The human-rights-subject, produced within the pages of the South African Bill of Rights (chapter two of the 1996 Constitution) and the Constitution (Government of South Africa 1993; 1996), and supposedly estranged from the pre-1994 South African conception of the apartheid citizen, was always central to the construction of human rights idolatry (Keet 2015) in post-1994 South Africa. Both human rights and transformative constitutionalism converged into a totalising narrative of progress and transformation amidst a landscape littered with broken human rights promises, especially 'widespread poverty', 
'extreme inequality', poor educational outcomes, societal exclusion, to name a few (National Planning Commission 2011).

Constitutional mechanisms emerged as the 'formal framers' of the rights discourse post1994. Thus, a massively productive project on developing and enacting social legislation took shape, ${ }^{4}$ confirming that constitutional and human rights discourses were at the apex of a 'designed' everyday public consciousness. Human rights became the official language of transition of law, politics and life in South Africa paving the way for transformative legislation in each and every social sector, including higher education and higher education governance. The rights-based policy architecture in higher education with provisions for the democratic participation of students, is rooted in this brief post-1994 history. These policy developments could not foresee the global elaboration of human rights into regimes of control and governmentality over the past two decades.

The 'regulatory' function of rights was already evident in the first phase of our study, mandating its retreatment. Retreat has two meanings here, as according to Lacoue-Labarthe and Nancy (Sparks 1997, xxvii). First, it may mean 'pulling back' or to 'withdraw'; and second - the meaning we use in this article by borrowing from the Lacoue-Labarthe and Nancy (1997) essays in Retreating the Political, it may alternatively mean the 'traversing and displacing' of the 'political' and its 'meaning' (Sparks 1997, xxvii) and retracing the contours of which 'actual conditions would need to be reinvented' (Lacoue-Labarthe and Nancy 1997, 139). In a similar vein, 'Retreating rights', as we have titled this article, intimates traversing and displacing rights and its meanings and retracing its contours outside the scope of a proceduralism that is linked to an increasingly administered society. Such a retreat 'must allow, or even impose, the tracing anew of the stakes of the political' (Lacoue-Labarthe and Nancy 1997, 131), the stakes of human rights, so as to release something or make something appear (ibid.) for us to be slightly freed from the 'blinding obviousness' (ibid., 114) of human rights. In this article, we attempt to retreat rights through exploring pre-theoretical human rights praxes in relation to student activism and to retrace the stakes embedded in its codified forms as a way to liberate us from its blinding obviousness that disallows praxes and traverses rights-based proceduralism.

Now that we have expounded on the meanings that we employ around the phrase retreating rights, the next logical step is to frame our understanding of pre-theoretical praxis to make the interpretive scheme of our study intelligible. Adapting from Honneth (2007a), Allen (2016, 80) defines pre-theoretical praxis as 'the empirical experiences and attitudes of social actors, particularly their experiences of injustice'. Thus, the need to retreat rights stems from its possible ineffectiveness to respond to empirical experiences of injustice. A growing body of 
knowledge, which we refer to as human rights critiques, is emerging that more or less has such retreatment in mind. We will return to these critiques later on.

The conceptual frames of our research study took shape during the informal discussions with students and student leaders that consisted of twenty-eight bilateral and seven group encounters between November 2011 and December 2012. The major issues that students formulated during these informal discussions suggested that despite the democratisation of university spaces through human rights related policies, the intuitive justice expectations that students have are not adequately facilitated by rights-based regimes. In other words, the practical expression of rights does not necessarily correlate with recognition. In May 2013, therefore, we conceptualised our study around a critical engagement with Honneth's theory of recognition (1995a; 1995b and 2007b) and imported particular understandings of student participation, citizenship and democratic practice. We also employed Bourdieu's (1984) notions of field and habitus and Foucault's (1977) concept of governmentality to make better sense of the constraints on agency, facilitated by rights, as expressed in students' experiences of 'acting out scripts' in an 'overregulated space'.

The demands to retreat rights and retrace its contours were already intimated in the first phase of the study. Seemingly, the sources for such retreat reside in students' pre-theoretical understandings of justice as a promise of human rights and democratisation. As we argued earlier, therefore, we employ Lacoue-Labarthe and Nancy’s (1997) concept of retreat and the notion of pre-theoretical praxes and their role in Honneth's recognition theory. We locate this conceptual scheme in critical theory broadly understood as an 'interdisciplinary social theory with emancipatory intent' (Zurn 2015, 4). The emancipatory intent of our study is linked to the objective to trace afresh the stakes of human rights so as to be marginally unregulated by its 'blinding obviousness' (Lacoue-Labarthe and Nancy 1997, 114).

According to Habermas's understanding of critical theory, the pre-theoretical resource for emancipation, is assumed in communicative action. 'Social pathologies can be understood as forms of manifestation of systematically distorted communication' (Honneth and Joas 1991, 229). Social ills can thus be linked to processes that compromise the ability of human beings to reach communicative understanding. For Honneth (2007a, 70) pre-theoretical resources for justice claims do not reside in communicative action, but rather, they exist in 'moral experiences as feelings of disrespect' (ibid., 71) because moral experiences are 'not aroused by restriction of linguistic capabilities, but by a violation of identity claims acquired in socialisation' (ibid., 70). Human beings do not encounter each other on the basis of communicative understanding; but rather, they have reciprocal expectations of receiving moral recognition as moral persons 
(see Honneth 2007a, 69-72).

Zurn's $(2015,45)$ summary of Honneth's conceptual basis suggests three forms of 'intersubjective recognition'5 - love (friendship), legal relations (rights), and solidarity (achievement) - corresponding to three forms of practical self-understanding - 'selfconfidence, self-respect, and self-esteem' - that underscore his critical social theory of recognition. Furthermore, intersubjective recognition also provides the architecture for his reconstructive, pluralist theory of justice: justice of needs (love, friendship); justice of deliberative equality (rights); and justice of achievement (solidarity) (Honneth 2012, 49). These principles of justice, in Honneth's argumentation, are empirically present in the everyday praxis of agents, intuitively so (ibid.). In the first phase of our research, it seems that student leaders' participation is particularly rooted on the first level of intersubjective recognition, a justice of needs (love, friendship); whilst the justices of deliberative equality and achievement are constrained by various factors (Keet and Nel 2016). Though Honneth (2007b) is acutely aware of the limits of rights, the contemporary role of rights in over-regulatory practices which hampers a justice of deliberative equality does not feature substantively in his critique of rights. This gap does not necessarily render parts of his recognition theory problematic or invalid; rather, it suggests that we will be better served to focus simultaneously on pre-theoretical understandings of rights and its codified forms. Consequently, the legal relations within which rights are captured and captive, consistently require a return to its non-juridical, normative foundations. Otherwise, rights tend to amplify proceduralism as the only mode of engagement and participation which is a pattern we identified that underscores findings in the first two phases of our study. The alternatives embedded within imaginations that are freed from the blinding obviousness of rights are cut off from their emergence.

We assume these imaginations are located within a pre-theoretical understanding of human rights. Students frame the justice-making potential of rights on a pre-theoretical level contingent on its prospects to contribute to reciprocal recognition. Students revealed that they also apply such frames in relation to the human rights codifications that have become the major orders of these justice-claims nationally and globally. The central puzzle for us then is to decipher whether the students may have the resources for social activism somewhere between the interaction of pre-theoretical and coded expressions of human rights. This activism, it seems from the first and second phases of the study, is generally constrained by human-rights-related proceduralism which makes human rights prone to be overtaken by new events (Honig 2001, 800). Rights, as a language, therefore, that aims at critiquing social injustice must (of necessity) be distrustful of its role in obscuring the very same injustices that it wants to address by 
returning, time after time, to its pre-theoretical source; ‘to give dead rights, live futures’ (ibid.).

In summary, the conceptual frame comes together in the following way. Honneth's theory of recognition (1995a; 1995b; 2007b), within which rights as legal relations are central, guides the research project. Given the fact that rights-based proceduralism emerged, during the first phase and second phase of the study, as constraining on student social activism, the need to renew rights became a principal concern. We thus mobilise Lacoue-Labarthe and Nancy's (1997) notion of retreat as a basis to think such renewal. Since there is a general assumption that rights advance agency, we employ Bourdieu's (1984) notions of field and habitus and Foucault's (1977) concept of governmentality to make better sense of the restrictions on agency from a rights-perspective.

\section{METHODOLOGICAL CONSIDERATIONS}

As components of an activist enterprise, retreatment and renewal of human rights are at the heart of this study, and they are probed as follows: If the emancipatory capacity of codified rights and the contingent link between human rights and the expansion of democratic practice are already empirically under question in the first phase of the study, where, if at all, are the alternative sources for human rights social activism located? The design of this study aims to examine this question, focusing on human rights understandings.

We regard our research as an exploratory study which followed a qualitative-interpretive research approach in the form of a stop-and-ask survey design. A team of sixteen student fieldworkers were trained in research ethics, data gathering skills in the stop-and-ask mode and the data gathering protocol used in this study. The fieldworkers also provided valuable inputs on how to improve the data gathering protocol, which consisted of four parts. In the first part, the student participants in the study were asked to provide anonymous biographical details of themselves. An open-ended question section served as the second part in which participants had described what 'being human' means to them. In the third part, participants were asked to numerically rank three rights presented in a table most important to them, what they thought the first three rights in the Bill of Rights are, and they had to choose three rights least important to them. In the fourth part of the protocol, participants were expected to write down the four challenges they regarded as most important in South Africa and at the University of the Free State (Bloemfontein campus), respectively. For a duration of four months, fieldworkers solicited consent for student participation at the university. A total of three hundred forty-eight protocols were returned to and processed by a research data manager.

Simple enumeration was used to manage the biographical data of the first and third parts 
of the protocol to summarise the data. The second and fourth parts of the protocol, which required participants to provide their own responses, were managed by thematic analysis. The analysis phase was followed by four focus group discussions that expanded upon the emerging thematic areas.

\section{FINDINGS AND ANALYSES}

The study expectedly shows that the legal and politically codified constructions of human rights are discursively dominant in students' minds. However, it appears, from the overall results of this phase of the study that students have more complex pre-theoretical understandings of human rights from which they derive justice-oriented normative standpoints as the basis for their understandings and applications of activism. Formal, codified human rights, therefore, play less of an agential function within student activism if detached from and unguided by pretheoretical human rights praxes. The implications for human rights praxes are obvious, and we discuss this later.

To study pre-theoretical understandings of human rights of university students is a daunting task given the over-proximity of the human rights language in our national political discourse. As a result of socialisation and educative processes, students demonstrated that they encountered the formalistic notions of human rights over an extended period of time. For instance, students showed they could readily list the first three rights in the Bill of Rights in the South African Constitution: the rights to equality, human dignity and life. (Government of South Africa 1996). Two hundred and seventy-four of the three hundred and forty-eight participants, representing 90.2 per cent of the total number of participants, specify 'equality' as the most important human right in their understanding. 'Human dignity' followed as the second most popular response at 75.6 per cent. The other rights did not attract more than 43 per cent of participants' ranking them as most important. The first three rights in the Bill of Rights were indicated in the following averaged sequence from first to third in terms of importance: 'Equality’ (82.8\%), 'life’ (76.2\%) and 'human dignity’ (57.2\%). These figures challenge the general assumption that South Africans have limited knowledge of rights and other constitutional provisions (Hodgson 2014) at least as far as human rights knowledge among university students is concerned.

Nevertheless, one can claim that 'equality' and 'human dignity' are two rights with pretheoretical links that align well with Honneth's three forms of 'intersubjective recognition' 6 discussed earlier, as well as his pluralist theory of justice: justice of needs (love, friendship); justice of deliberative equality (rights); and justice of achievement (solidarity) (Honneth 2012, 
49). We can also link the findings on the rights to 'equality' and 'human dignity' to Habermas's (2012) exposition of the centrality of the concept of 'human dignity' that provides human rights retrospectively with moral force. The 'outrage of the humiliated at the violation of their human dignity’ (Habermas 2012, 75), interpreted by Honneth (1995b) as feelings of social disrespect, precedes and sublates the codification of human rights. 'Sublation' here is used in the Hegelian sense of aufheben meaning to 'preserve, to maintain, and equally it also means to cease, to put an end to' (Palm 2009, 8). These two meanings function simultaneously; affirming and disclaiming human rights at one and the same time. This approach is one way in which rights can be reinvested with social justice potential. Also, the centrality of 'equality' and 'dignity' in students’ responses may also signify, as Chatterjee (2004) would argue, a desire to be simultaneously inside and outside of human rights codifications. If human rights praxes, ingrained in formalised human rights provisions, partly contribute to the misrecognitions of the majority of poor people across the world, then moral feelings of disrespect, of having one's dignity violated, will always already have the capacity to reinvest a social activist capacity in human rights. This argument was particularly pronounced in the focus groups discussions.

To further probe their pre-theoretical understandings of human rights students were asked to, in an open-ended style, write the concepts down that for them describe the 'human' in human rights. 'Care and empathy for the other' (35\%), having rights and responsibilities (19.5\%), and 'respect for self and others' (19\%) are the three major themes that have emerged. If we cluster 'care and empathy for the other' and 'respect for self and others', then more than 54 per cent of participants' intuitive notions of human rights hover within the vicinity of 'human dignity'. It also points to 'recognition' as generated by and dependent on intersubjective relations amongst human beings, a logic that lines up well with both Habermas's and Honneth's interpretive schemes. The same goes for 'rights and responsibilities' as central to the 'human' in human rights.

In the four focus group discussions, students were encouraged to reflect on their knowledge of human rights in relation to the challenges they experienced at the university. In terms of the survey, 40 per cent regard 'racial discrimination' as the major challenge, whilst 22 per cent think that socio-economic inequalities are the principal issue on the university campus. Combining these figures places 'equality' as the key organising theme for 62 per cent of the participants who framed the key contestations in their everyday lives as student citizens. Nevertheless, when probed as to why such patterns are not employed to mobilise for social activism, students tend to argue that rights are imprisoned by governmentality; a theme that we pursued in 'Rights, regulation, recognition' (Keet and Nel 2016). In a sense, retrospectively 
speaking, the leading segment of the student protests between 2015 and 2016 rested on demands for equality, dignity and recognition. These demands were performed, not through formal human rights notions, but through human rights outsides as an affective, morally-charged, nonjuridical discourse which includes testing the plasticity between proceduralist legality and nonproceduralist illegality. These findings suggest that students have the retreatment of rights in mind; 'to give dead rights, live futures' (Honig 2001, 800). There are four themes emerging from the findings.

- $\quad$ First, though Honneth does not have a strong critique of rights in mind in his recognition theory, the study shows that his insistence on a pre-theoretical source for indignation rooted in the social dynamics of disrespect (Honneth 1994; 2007a) points in the direction of such critique from the need for the retreatment of rights stem.

- Second, though codified rights are strongly integrated into students' conceptions of justice, they are well aware of how it augments governmentality and thus either smother or steer social activism.

- $\quad$ Third, the centrality of equality and human dignity in students' pre-theoretical framings of human rights opens up the possibilities to continuously reinvest it with an activist potential.

- $\quad$ Fourth, students simultaneously affirm and disclaim rights; they want to be inside and outside rights at one and the same time. We further explore these themes in the next section.

\section{REFLECTIONS}

The findings of the study suggest that the muting effects of rights can be countered by bringing into play the normative conceptions of justice that are always already present in pre-theoretical praxes as a revitalising resource for human rights work. However, it would require a serious rethinking of global human rights praxes; one in which human rights critiques are given more prominence. Thus, though codified human rights are clearly central in students' conception of social activism, it is the critiques of rights that can slice open the pathways for rights to consistently return to its pre-theoretical basis. This understanding brings us to the first of the themes emerging from the study - the critique of rights.

The critique of rights has a long history but its substance has escaped contemporary human rights praxes. In 1789, Bentham famously dismissed rights as 'simple nonsense: natural and imprescriptible rights, rhetorical nonsense, - nonsense upon stilts’ in 1776 (cited in Gündoğdu 
2015, 12). Madlingozi (2014) advances three categories of critiques against human rights discourses. First, the Marxist and neo-Marxist critique holds that 'legalism' can induce a false consciousness whereby radical demands are transmuted into [sterile] 'human rights' claims. Second, the critique on a tactical level argues that 'in liberal democracy the human rights discourse has so much currency as the only legible script of emancipation that once deployed, inevitably, it over-shadows other radical discourses that speak to problems of political economy, etc.' (ibid.). The third category of critiques suggests that 'in historically white supremacist societies, Euro-American modernist constitutions like that of South Africa simply perpetuates whiteness as a system of privilege’ (ibid.).

Human rights critiques also feature in Arendt's philosophical corpus, as discussed in Villa's (2000) The Cambridge Companion to Hannah Arendt. Two key elements of her critique are the absence of the right to have rights and the fact that such rights cannot be considered 'as substance, but only as a necessary precondition of political freedom' (Villa 2000, 223). Other types of critique are found in this succinct summary below by Gündoğdu $(2015,12)$ :

\begin{abstract}
Some critics see the discourse of human rights, especially as it is utilised in the new practice of international humanitarian intervention, as a distinct type of neo-imperialism. Some others highlight more subtle forms of political power at work in this discourse and suggest that human rights subject us to the very state power from which they promise to protect us. What is more troubling, they contend, is that this hegemonic discourse has such a strong hold on our political imagination that it has become almost impossible to invent alternative forms of politics that can bring to light different understandings of equality, freedom, justice, and emancipation.
\end{abstract}

In line with these categories of critique, Balibar $(2013,18)$ suggests that human rights can maintain standard politics 'only on the condition of being radically revisited'. This argument supports the contention here to retreat rights. In addition, human rights critiques have been classified by Schippers (2016) as 'human rights purported regulatory, disciplinary and exclusionary effects; ... [the] anthroprocentric assumptions underpinning rights discourse; ... [and its] predilection for "jurocratic rule" at the expense of democratic practices'. In response to these critiques, a growth in critical human rights studies is taking root (Columbia Law School 2016; ${ }^{7}$ Douzinas 2013; ${ }^{8}$ Madlingozi 2014; Schippers 2016) a welcome development in all respects.

Far from being dismissive of rights or anti-rights, human rights critiques appear to carry the prospects to retreat (Lacoue-Labarthe and Nancy 1997, 139), recraft (Honig 2001, 800), and radically revisit (Balibar 2013, 18) rights as an exercise of fidelity and renewal. ${ }^{9}$ We 'have to recognise the tangible improvements that human rights, solidarity and development have achieved' (Douzinas and Gearty 2014, 9). However, if rights is 'the necessary and impossible 
claim of law to justice' (Douzinas 2000), then it also serves as 'the utopian futural aspect of law' (Douzinas 2000). Thus, human rights, as the promise of law underlying justice, will always be within and beyond the law, as well as inside and outside of procedure. Therefore, given the assimilation of rights into jurocratic praxes that serve to reproduce injustices, as highlighted by rights critiques, retreating rights should be the prevailing vocation of human rights activists. These critiques and paradoxes of rights as un/freedoms surfaced throughout the findings of the study.

The second theme relates to how students, within their own subjective location as rights bearers of codified rights, employ these rights in 'the democratic legal relations [of] deliberative equality' (Honneth 2012, 49). Even as they sense and experience the suffocating effects of rights on social activism, they make tactical choices on how to employ rights on the basis of their intuition that it should and could do more. In essence, students prefer to operate in the fluid space between formalised and pre-theoretical understandings for human rights. Nevertheless, we suspect that even as Honneth (ibid.) ponders the 'limits of contemporary proceduralism', he does not go far enough in considering human rights critiques in his theoretical positions.

The third theme emerging from the findings is the centrality of the rights to 'equality' and 'human dignity' in students' pre-theoretical framings of human rights. Human rights, in its formalised constructions, are, without doubt, folded into global contemporary politics and democratic practice. It is constitutive of the police, as evident in Rancière's (2004a, 28) logic:

Politics is generally seen as the set of procedures whereby the aggregation and consent of collectivities is achieved, the organisation of powers, the distribution of places and roles, and the systems for legitimising this distribution. I propose to give this system of distribution and legitimisation another name. I propose to call it the police.

As part of a legitimating 'set of procedures', one may say human rights have become a central ruse within present theories and practice of democracy. The point of policing is 'to prevent the active expression of equality by those who are not in charge of their political lives' (May 2008, 47). The concept of equality features as the apex of Rancière's political philosophy (see May 2008), serving as a presupposition of democratic politics and the invocation of dissensus 'from the current social order' (May 2008, 43). The presupposition of equality disrupts the police; and it interrupts policing. It calls to retreat rights in order to work against its policing functions. Moser (2012) ${ }^{10}$ argues: 'Equality seems to be an intuitive aspect of our thinking', while Habermas (2010) suggests that our intuition tells us that human dignity has always been the morally-charged demand that underwrites the human rights discourse. Apparently, students are 
aware that the limits of codified rights can be challenged and overcome by recourse to the pretheoretical sources inherent in the demands for equality and human dignity as a way to radically revisit rights.

On a similar logical track as the first three themes, the fourth argument that emerged suggests that students simultaneously affirm and disclaim rights; they want to be inside and outside rights at one and the same time. One way of approaching this 'contradiction' is to argue it through Rancière's (2004b) notion of the police that functions to present state authority as the terminal point of political consciousness which disallows the materialisation of political outsides (Keet 2014). Thus, a politics next to the state or outside the state are both incomprehensible. Therefore, as constitutive of the police, if conventionally understood, human rights can contribute to this disallowance; and thus, the non-appearance of its own outsides. However, the praxes of students captured within the formulations of their own understandings of human rights that simultaneously affirm and reject human rights, can only become intelligible by considering the continual interplay between codified and pre-theoretical understandings of human rights via human rights critiques. In addition to the notion of police that helps us think about human rights insides and outsides, Rancière's (2011) concept of dissensus is equally important. Dissensus refers to the idea that if politics is based on the human capacity of speaking and discussing, this capacity is split up from the very beginning. It follows that this split-up capacity of speaking and discussing always already generate human rights insides and outsides in the way in which agents choose to employ rights. That is, Rancière wants to put forward, in the most direct formulation of his idea of dissensus as far as human right are concerned, a division in the common sense of human rights; to release us from its blinding obviousness, to retreat it (Du Preez and Becker 2016).

\section{CONCLUSION}

Retrospectively, the general route of the study seems - at least partially - to postulate one interpretive scheme for making sense of student experiences that gave rise to the contemporary student protests in South Africa whose causes are both overdetermined and understudied. Nevertheless, it is probably reasonable to suggest that the sources of the justice demands ${ }^{11}$ articulated by students reside in a pre-theoretical praxis that have the retreatment of rights in mind. As this research at least is highlighting parts of the aporetic nature of rights, its infinite perplexities and paradoxes, we may already be in a position to better grasp why students want to be inside and outside human rights at one and the same time. Whilst codified rights, the rights insides, do allow for productive forms of social activism, students also source the basis 
for activism in their pre-theoretical understandings of rights, human rights outsides, which according to the findings of the first two phases of the research project, have a more pronounced justice-orientation than its insides.

In terms of student participation in the life of universities, a range of structures and processes make provision for rights and duties within the parameters of a deliberative model. ${ }^{12}$ This model, as phase one of our study demonstrates (Keet and Nel 2016), is questioned because of its proceduralist and regulatory inclinations that seem to constrain student leaders' expression of citizenship as action. The idea of rights as un/freedoms stems from students' claims to be inside and outside of human rights at one and the same time. To be inside of human rights is to work with its calculable democratic advantages. To be outside of human rights is not a rejection of rights; rather it is to extend rights' promise of justice beyond its own limits, to paraphrase Derrida in the words of Haddad $(2013,48)$.

The calculable democratic advantages of rights, expressed as broad-based student participation in governance and university life in this instance, also regulate the form and function of student protests. For instance, there is the responsibility to deliberate and the right to protest, but in a specific way that is usually prescribed by law, policy, regulations and codes of conduct which are crucial for the pragmatic functioning of universities.

Nevertheless, if we become mindful of the aporetic nature of rights, we may be able to see how rights, facilitate freedom and over-regulation; as is also the case in the over-regulation of student participation regimes (Keet and Nel 2016). This suggests that we are yet to generate praxes, including management practices, where the quantifiable benefits of rights are continuously expanded, and not constrained, by human rights outsides. A praxis that is of necessity both burdened by pragmatism and unburdened by justice-imaginations and allows for regulated and non-regulated (not violent), yet productive change. On this score, both the understandings and teachings of human rights that are expressed in human rights praxes would require thoughtful and radical renewal with pragmatic import.

\section{NOTES}

1. Andre Keet and Willy Nel started the formal research project in 2013; they were joined by Sahar D. Sattarzadeh in 2016.

2. This is understood to be the capacity to exercise rights and responsibilities, the proficiency to express membership, and the competencies to participate and claim recognition as argued by Lister et al. (2007)

3. International human rights non-governmental organisations such as Amnesty International (AI) are most known for their extensive human rights campaigns around the globe even though they are all Western-based. These organisations have recorded many successes based on a rights-based approach.

4. Gutto (2001, 7-11) refers to more than fifty laws that were enacted between 1994 and 2000 in the 
areas of equality, land, housing, natural resources, environment, development, education, labour, health, sports, recreation, culture and welfare. In each of these sectors, non-discrimination and the promotion of equal rights form the foundation.

5. Honneth (1995b, 93): Chapter five of The Struggle for Recognition.

6. Ibid.

7. Columbia Law School offers as course in 'Critical Human Rights Theory'. More information is available at: http://www.law.columbia.edu/courses/sections/19707.

8. Costas Douzinas, 'Seven Theses on Human Rights: (5) Depoliticisation', Critical Legal Thinking: Law and the Political (blog), 31 May 2013, http://criticallegalthinking.com/2013/05/31/seventheses-on-human-rights-5-depoliticisation/.

9. This notion is most evident in the reflections and chapters complied in The Meanings of Rights: The Philosophy and Social Theory of Human Rights (Douzinas and Gearty 2014).

10. Andreas Moser, 'Equality Versus Sufficiency', The Happy Hermit (blog), 21 May 2012, https://andreasmoser.blog/2012/05/21/equality-versus-sufficiency/.

11. Although fallist students' demands within and across universities are not necessarily unified in their visions and motivations (Ebrahim 2016), there are some common calls for justice shared across FMF movements, including, but not limited to: the guarantee of free higher education for all; 'decolonisation' of higher education institutions; freedom and the right to protest without disciplinary consequences; a cancellation of all student debt; an end to outsourcing of service workers; and the removal of privatised police and security from university and college campuses.

12. Koen, Cele and Libhaber (2006) observe that the underlying assumptions of the higher education legislative framework are linked to the notion of deliberative democracy, rational discussion and agreement.

\section{REFERENCES}

Allen, A. 2016. The end of progress: Decolonising the normative foundations of critical theory. New York: Columbia University Press.

Balibar, E. 2013. On the politics of human rights. Constellations 20(1): 18-26.

Bourdieu, P. 1984. Distinction: A social critique of the judgement of taste. London: Routledge.

Butler, J. 2010. Frames of war: When is life grieveable? London: Verso.

Chatterjee, D. K. 2004. The ethics of assistance: Morality and the distant needy. Cambridge: Cambridge University Press.

Douzinas, C. 2000. The end of human rights. Oxford: Hart Publishing.

Douzinas, C. and C. A. Gearty. 2014. The meanings of rights: The philosophy and social theory of human rights. Cambridge: Cambridge University Press.

Du Preez, P. and A. Becker. 2016. Ontologies and possibilities of human rights: Exploring dissensus to facilitate reconciliation in post-conflict education contexts. Perspectives in Education 34(3): 114.

Ebrahim, S. 2016. These are the divisions separating students in the \#FeesMustFall movement, The Daily Vox, 27 September. http://www.thedailyvox.co.za/no-united-student-movement-sweepingacross-country/ (accessed 9 February 2017).

Foucault, M. 1977. Discipline and punish: The birth of the prison. New York: Random House.

Government of South Africa. 1993. Constitution of the Republic of South Africa Act 200 of 1993. http://www.gov.za/documents/constitution/constitution-republic-south-africa-act-200-1993 (accessed 1 February 2017). 
Government of South Africa. 1996. Constitution of the Republic of South Africa. http://www.gov.za/ documents/constitution/constitution-republic-south-africa-1996-1\%20 (accessed 1 February 2017).

Gündoğdu, A. 2015. Rightlessness in an age of rights. Hannah Arendt and the contemporary struggles of migrants. Oxford: Oxford University Press.

Gutto, S. 2001. Equality and non-discrimination in South Africa: The political economy of law and law making. Cape Town: New Africa Books.

Habermas, J. 2010. The concept of human dignity and the realistic utopia of human rights. Metaphilosophy 41(4): 464-480.

Habermas, J. 2012. The crisis of the European Union. Maldon, MA: Polity Press.

Haddad, S. 2013. Derrida and the inheritance of democracy. Bloomington: Indiana University Press.

Hodgson, T. F. 2014. Op-Ed: Only 46\% of South Africans have heard of the Constitution and Bill of Rights. Daily Maverick, 20 April. https://www.dailymaverick.co.za/article/2014-04-28-op-edonly-46-of-south-africans-have-heard-of-the-constitution-and-bill-of-rights/\#.WKlL0_naeCg (accessed 5 February 2017).

Honig, B. 2001. Dead rights, live futures: A reply to Habermas's 'constitutional democracy'. Political Theory 29(6): 792-805.

Honneth, A. 1994. The social dynamics of disrespect: On the location of critical theory today. Constellations 1(2): 255-269.

Honneth, A. 1995a. The fragmented world of the social. New York: SUNY Press.

Honneth, A. 1995b. The struggle for recognition. The moral grammar of social conflicts. Cambridge: Polity Press.

Honneth, A. 2007a. Disrespect: The normative foundations of critical theory. Cambridge: Polity Press.

Honneth, A. 2007b. Recognition as ideology. In Recognition and power: Axel Honneth and the tradition of critical social theory, ed. B. van den Brink and D. Owen, 323-347. Cambridge: Cambridge University Press.

Honneth, A. 2012. The I in we: Studies in the theory of recognition. Cambridge: Polity Press.

Honneth, A. and H. Joas. 1991. Communicative action essays on Jürgen Habermas's The Theory of communicative action. Cambridge: Polity Press.

Keet, A. 2014. Spectacle and spectators: Higher education and the 'disappearance' of democracy. South African Journal of Higher Education 28(3): 849-865.

Keet, A. 2015. It is time: Critical human rights education in an age of counter-hegemonic distrust. Education as Change 19(3): 46-64.

Keet, A. and W. Nel. 2016. Rights, regulation and recognition: Studying student leaders' experiences of participation and citizenship within a South African university. International Journal of Educational Sciences 13(1): 129-144.

Koen, C., M. Cele and A. Libhaber. 2006. Student activism and student exclusions in South Africa. International Journal of Educational Development 26(4): 404- 414.

Lacoue-Labarthe, P. and J. Nancy. (Eds.). 1997. Retreating the political. London: Routledge.

Lister, R., F. Williams, A. Anttonen, J. Bussemaker, U. Gerhard, J. Heinen, S. Johannson and A. Leira. 2007. Gendering citizenship in Western Europe: New challenges for citizenship research in a cross-national context. Bristol: Policy Press.

Luescher, M. T. 2015. Theorising student activism in and beyond the 20th Century: The contribution of Philip G. Altbach. In Student engagement in Europe: Society, higher education and student governance, ed. M. Klemenčič, R Primožič and S Bergan, 33-50. Strasbourg: Council of Europe Publishing.

Luescher, T. M., M. Klemenčič and J. O. Jowi. 2016. Student politics in Africa: Representation and activism. Oxford: African Books Collective. 
Madlingozi, T. 2014. 'There is no "outside the law": How can social movement use the law to bring about radical change and social justice?'. NGOs and Social Justice in South Africa, 26 May. http://thinkingafricangos.blogspot.co.za/2014/05/there-is-no-outside-law-how-can-social.html (accessed on 1 February).

May, T. 2008. The political thought of Jacques Rancière: Creating equality. Edinburgh: Edinburgh University Press.

National Planning Commission. 2011. Diagnostic overview. www.education.gov.za/LinkClick.aspx? fileticket=FdWq5BIbHkY=\&tabid=889 (accessed 1 February 2017).

Rancière, J. 2004a. Disagreement: Politics and philosophy, translated by Julie Rose. Minneapolis: University of Minnesota Press.

Rancière, J. 2004b. Who is the subject of the rights of man? The South Atlantic Quarterly 103(2/3): 297-310.

Rancière, J. 2011. The thinking of dissensus: Politics and aesthetics. In Reading Rancière, ed. P. Bowman and R. Stamp, 1-17. London: Continuum.

Schippers, B. 2016. 'Rights-claiming, performativity, and the politics of human rights.' Political Studies Association. https://www.psa.ac.uk/node/19406 (accessed 1 February 2017).

Sparks, S. 1997. Introduction: Politica ficta. In Retreating the political, ed. P. Lacoue-Labarthe and J. Nancy, xiii-xiv. London: Routledge.

Villa, D. 2000. The Cambridge companion to Hannah Arendt. Cambridge: Cambridge University Press.

Zurn, C. 2015. Axel Honneth. Cambridge: Polity Press. 